\title{
A SOCIOLOGIA DUAL DE ROBERTO DA MATTA: Descobrindo nossos mistérios ou sistematizando nossos auto-enganos?
}

\section{Jessé Souza}

Apesar das observações críticas que serão desenvolvidas no decorrer deste artigo, quero, antes de tudo, ressaltar a relevância da obra de Roberto Da Matta para a ciência social brasileira. Obra que se destaca pelo potencial inovador e pela centralidade da reflexão filosófica, seja na indagação acerca dos pressupostos da teorização científica, seja no questionamento radical do que constitui a singularidade de uma formação social.

Ao tentar descobrir "o que faz o brasil, Brasil", Da Matta propõe o questionamento de temas tais como o que é indivíduo?, o que é democracia?, o que são relações sociais?, como se compara sociedades? e, acima de tudo, como se percebe aquelas diferenças históricas e culturais que conferem uma especificidade toda própria a cada sociedade singular? Essas questões são essenciais posto que remetem a uma reflexão de pressupostos, permitindo a discussão daquelas indagações primordiais que, numa concepção de ciência "pragmática" e empiricista, já estão respondidas a priori. E sabemos que é precisamente a expansão do espaço da reflexividade que caracteriza a atitude científica e é a discussão dessas questões primordiais que permitem o pensamento crítico e inovador.

\section{O dilema brasileiro para Roberto Da Matta}

No caso de Da Matta, o fio condutor mesmo de sua reflexão já apontava para o desejo de surpreender a realidade brasileira por detrás de suas auto-imagens consagradas. Assim, em Carnavais, malandros e heróis (Da Matta, 1981), seu livro mais importante, essa tentativa é empreendida a partir do estudo do cotidiano brasileiro, no estudo dos seus rituais e modelos de ação portanto, que é onde podemos reencontrar nossos malandros e nossos heróis.

Desde o início, o esforço comparativo já temo seu "outro" privilegiado: os Estados Unidos. Interessa a Da Matta demonstrar, numa oposição que irá assumir inúmeras variações, por que nunca dizemos "iguais mas separados" como lá, mas, ao contrário, dizemos sempre "diferentes mas juntos" (Da Matta, 1981, p. 16). A comparação, nesse sentido, privilegia sempre o contraste, a contradição, e não o familiar, o semelhante, o co-extensivo.

O método é o estrutural, enfatizando as possibilidades de combinação alternativas e as ênfases distintas de elementos dominantes e subordinados de cada sistema social analisado. Assim, as catego- 
rias mais gerais do raciocínio do autor, as de indivíduo e pessoa, articulam-se de forma peculiar em cada sociedade. O indivíduo, no Brasil, não seria uma categoria universal e englobadora como nos Estados Unidos, nem apenas o renunciante, como na Índia. O indivíduo entre nós seria o joãoninguém das massas, que não participa de nenhum poderoso sistema de relações pessoais.

O indivíduo, entre nós, se definiria pela oposição com o seu contrário: a pessoa. Esta, por sua vez, se definiria como um ser basicamente relacional, uma noção apenas compreensível, portanto, por referência a um sistema social onde as relações de compadrio, de família, de amizade e de troca de interesses e favores constituem um elemento fundamental. No indivíduo teríamos, ao contrário, uma contigüidade estrutural com o mundo das leis impessoais que submetem e subordinam. Desse modo, teríamos no Brasil, ao contrário tanto dos Estados Unidos quanto da Índia, um sistema "dual" e não um sistema unitário. A questão essencial para Da Matta, portanto, já está posta: trata-se, no caso brasileiro, de perceber a " dominância relativa de ideologias e idiomas através dos quais certas sociedades representam a si próprias" (Da Matta, 1981, p. 23). Nesse sentido, nossa especificidade seria nossa dualidade constitutiva.

Na verdade, Da Matta (1991, pp. 24-29) procura relacionar o que ele considera como sendo duas leituras da realidade brasileira que seriam vistas comumente como antagônicas: uma "institucionalista”, a qual destacaria os macroprocessos políticos e econômicos, segundo a lógica da economia política clássica e implicando, por isso mesmo, alguma forma de diagnóstico pessimista do Brasil; e outra vertente, a qual se poderia chamar de "culturalista", cuja ênfase seria concedida ao elemento cotidiano dos usos e costumes, da nossa tradição familística ou "da casa", na linguagem de Da Matta. Sua própria perspectiva seria, portanto, superadora e sintetizadora dessas perspectivas parciais, unindoas e relacionando-as como duas faces de uma mesma moeda, transformando essas visões unilaterais num "dualismo" articulado.

Um olhar atento descobre que a cada uma dessas perspectivas correspondem, respectivamente, uma "sociologia do indivíduo" — a vertente institucionalista — e uma "sociologia da pessoa" a vertente culturalista. Ao unir e relacionar as duas perspectivas dentro de um mesmo quadro de referência teórico, Da Matta acredita ter percebido a "gramática profunda" do universo social brasileiro. Veremos mais adiante que o acesso a essa gramática exigiria a superação do próprio dualismo. Permaneçamos, no entanto, ainda um instante, dentro do próprio horizonte aberto pelo dualismo damattiano. Em que consiste esse dualismo e como Da Matta o constrói?

Vimos que seus termos mais abrangentes são as noções de indivíduo e pessoa. Esse é o dado fundamental e primário, na medida em que todos os outros são decorrência desse antagonismo fundamental. Assim, outras dualidades importantes para Da Matta, como aquela entre a casa e a rua, por exemplo, que deu o título a um dos seus livros, são decorrentes da oposição entre indivíduo e pessoa na medida em que indicam "espaços" privilegiados onde cada uma dessas modalidades de relações sociais se realizariam.

À oposição entre a casa e a rua corresponderiam, por sua vez, "papéis sociais, ideologias e valores, ações e objetos específicos, alguns inventados especialmente para aquela região no mundo social" (Da Matta, 1981, pp. 74-75). Nesse sentido, os nossos rituais são analisados e compreendidos a partir dessa oposição casa/rua e se distinguem entre si na forma e modo específico de lidar com esse antagonismo. Assim, a procissão religiosa teria sua peculiaridade no fato de permitir, durante um breve instante, a supressão da dicotomia casa/rua. O santo, para o qual a procissãoé realizada, "eleva-se" acima da dicotomia, suspendendo suas lealdades e sentimentos respectivos, criando, por alguns instantes, uma lealdade específica, sintetizadora, em relação a um novo campo de ação: o do sagrado.

$\mathrm{Na}$ parada militar, por oposição, o mundo das casas não é irmanando na devoção ao santo comum, mas é de certa forma "invadido" pelo Estado, que "recruta" e hierarquiza seus membros sob a forma de participantes humildes (os soldados), diferenciados (as autoridades) ou meros espectadores (o povo indiferenciado e tornado massa). A singularidade do Carnaval, por sua vez, residiria no fato de a rua tornar-se casa por alguns 
dias. Uma casa que celebra em praça pública o mundo da "cintura para baixo", o qual em dias normais é escondido dentro de casa, uma casa que torna seguro ( sic) o ambiente desumano de competição hostil que caracterizaria a rua. Ao mesmo tempo, a rua transformada em casa subverte tanto o código (hierárquico) da rua quanto o da própria casa. Daí o Carnaval ser uma perfeita inversão da realidade brasileira: é uma festa sem dono num país que tudo hierarquiza (Da Matta, 1981, p. 116).

No entanto, é apenas no ensaio "Você sabe com quem está falando?" que encontramos uma condensação de todos os aspectos desenvolvidos na interpretação "damattiana" da realidade brasileira. O ritual autoritário do "você sabe...", ao contrário dos anteriores, é um ritual cotidiano, do cotidiano hostil da rua, bem entendido, e no qual qualquer brasileiro, mesmo aquele que não brinca Carnaval, não assiste a paradas militares ou acompanha procissões religiosas, se reconhece facilmente.

Para Da Matta, o "você sabe..." põe a nu, revela à luz do dia um traço que o brasileiro não gosta e prefere esconder. Afinal, o que viria à tona aqui não seria mais a nossa celebrada e carnavalizada cordialidade, mas, ao contrário, o verdadeiro e profundo "esqueleto hierarquizante de nossa sociedade" (Da Matta, 1981, p. 142). Esse ponto é absolutamente fundamental tanto para o argumento do autor quanto para a crítica que iremos fazer mais adiante. É que, ao contrário da análise dos outros rituais extracotidianos, os quais permitem um tratamento que enseja uma assepsia classificatória (entre casa, rua e outro mundo ou Estado, povo e Igreja) que parece algo arbitrária no seu esforço de fazer corresponder práticas a espaços sociais delimitados, o "você sabe..." condensa e unifica todos esses aspectos e lança a questão central da articulação e hierarquização específica de todos esses elementos. Afinal, como se combinam indivíduo e pessoa ou casa e rua? Qual é o elemento dominante e qual o subordinado?

Da Matta não responde a essa questão de forma clara. Ele muitas vezes prefere enfatizar o componente aberto dessa competição entre princípios de organização social, o que de resto, na sua visão, permitiria caracterizá-la como o âmago mes- mo do "dilema brasileiro". ${ }^{1}$ No entanto, uma análise atenta de sua obra permite coletar uma série de indícios interessantes para nossos propósitos. As palavras "esqueleto" e "núcleo" que Da Matta usa constantemente para se referir ao componente hierárquico da formação brasileira são sintomáticas. Afinal "esqueleto" ou "núcleo" referem-se a alguma coisa escondida, a qual não seria imediatamente visível como a pele ou a superfície que os recobre, mas que nem por isso deixa de ser mais importante e mais substancial que o componente envolvente.

E é precisamente a mesma lógica que uma análise sistemática do ritual do "você sabe..." nos mostra. Senão, vejamos. O ritual envolve sempre uma oposição entre um dado individualizante ao mesmo tempo mais visível e mais superficial, posto que o elemento universalizante e igualitário seria o único discurso oficial e legítimo, e um componente pessoal e hierárquico mais profundo e menos visível (posto que não precisaria ser falado), mas que é o componente mais decisivo e eficaz do drama social em questão na medida em que resolve o conflito e restaura a paz hierárquica ameaçada.

É este último elemento, portanto, que Da Matta chama de "esqueleto" ou "núcleo" hierárquico, o elemento que atualizaria a gramática social mais profunda de uma sociedade como a brasileira. É a sua desagradável aparição no cotidiano que restaura a paz hierárquica perturbada por quem levou a sério o princípio igualitário e teve de ser lembrado "do seu lugar". O ritual é "desagradável" precisamente porque verbaliza o que não deveria ser dito para ser eficaz, quebrando assim o pacto silencioso e cordial de uma sociedade em que cada um efetivamente deve conhecer o "seu lugar".

[...] no drama do "você sabe com quem está falando?" somos punidos pela tentativa de fazer cumprir a lei ou pela nossa idéia de que vivemos num universo realmente igualitário. Pois a identidade que surge do conflito é que vai permitir hierarquizar.[...] A moral da história aqui é a seguinte: confie sempre em pessoas e em relações (como nos contos de fadas), nunca em regras gerais ou em leis universais. Sendo assim, tememos (e com justa razão) esbarrar a todo momento 
com o filho do rei, senão com o próprio rei. (Da Matta, 1981, p. 167)

Assim, e esse ponto é absolutamente fundamental tanto para a compreensão do argumento do autor quanto para a crítica que será feita adiante, é o elemento pessoal que é visto como dominante em relação ao elemento abstrato, legal, que se refere ao mundo dos indivíduos indiferenciados. Mas como eles se articulam? Até onde a validade parcial do elemento impessoal tem alguma eficácia? Como se dá a combinação específica entre os dois princípios?

É como se tivéssemos duas bases através das quais pensássemos o nosso sistema. No caso das leis gerais e da repressão, seguimos sempre o código burocrático ou a vertente impessoal e universalizante, igualitária, do sistema. Mas no caso das situações concretas, daquelas que a "vida" nos apresenta, seguimos sempre o código das relações e da moralidade pessoal, tomando a vertente do "jeitinho", da "malandragem" e da solidariedade como eixo de ação. Na primeira escolha, nossa unidade é o indivíduo; na segunda, a pessoa. A pessoa merece solidariedade e um tratamento diferencial. O indivíduo, ao contrário, é o sujeito da lei, foco abstrato para quem as regras e a repressão foram feitos. (Da Matta, 1981, p. 169)

De acordo com essa ótica, a lei geral e abstrata teria uma validade de primeira instância. Afinal, ela pressupõe uma igualdade de "partida" que bem pode ser confirmada como verdadeira no ponto de "chegada", ou seja, nos casos concretos do dia-a-dia e do cotidiano de todos nós. No entanto, em caso de conflito, o caso concreto obedeceria a outros imperativos que não àquele da lei geral. Precisamente aqui entraria o componente das relações pessoais, do "capital" que se acumula em termos de contato e influência. Seria como se as relações pessoais entre nós desempenhassem o papel do Judiciário nos países individualistas e igualitários. Como cabe ao Poder Judiciário dirimir conflitos a partir dos casos concretos, teríamos, no nosso caso específico, uma resolução "informal", sem burocracia e rápida: através da "carteirada", do jeitinho, da ameaça velada e do "você sabe...". No caso concreto, não aplicamos a lei geral ao caso específico, mas a força relativa de nossas relações pessoais. Em outras palavras, ou melhor, nas palavras do próprio autor: "'o você sabe...' permite estabelecer a pessoa onde antes só havia o indivíduo" (Da Matta, 1981, p. 170).

Esse tipo de solução é extremamente problemático sob o ponto de vista da fundamentação teórica do dualismo proposto por Da Matta. Afinal, levada às suas últimas conseqüências, essa solução implica afirmar que os brasileiros se comportam de um modo inverso aos estímulos das instituições sociais fundamentais, como Estado e mercado. Esse nó conceitual não é de fácil solução já que Da Matta vincula habilmente a auto-imagem folclórica do brasileiro com análises concretas de rituais facilmente observáveis na realidade cotidiana. A evidência e eficácia desse tipo de discurso é enorme. Nesse sentido, peço a paciência do leitor para que possamos nos concentrar nos meandros de uma análise dos pressupostos desse tipo de discurso teórico.

\section{Gramática profunda ou dualismo superficial?}

O dualismo engendrado pelas noções de indivíduo e pessoa como a base do que Da Matta chama de "dilema brasileiro" 2 foi desenvolvido ao longo das décadas de 80 e 90 seja em trabalhos de divulgação (Da Matta, 1999a), seja em livros como A casa e a rua, onde a dimensão espacial da dualidade ganha proeminência é analisada em maior detalhe. Eu gostaria agora de continuar a discussão em dois passos: primeiro, desenvolvendo uma apreciação crítica da perspectiva do autor e, em seguida, procurando reconstruir uma resposta alternativa às questões deixadas em aberto pelo esquema damattiano.

Inicialmente vou me deter nas próprias idéias de sociedade e teoria social, as quais, segundo Da Matta, são subjacentes à sua análise. No livro A casa e a rua encontramos a seguinte definição:

A idéia de sociedade que norteia esse livro, portanto, não é aquela da sociedade como um conjunto de indivíduos, com tudo o mais sendo mero epifenômeno ou decorrência secundária de seus interesses, ações e motivações. Ao contrário, so- 
ciedade aqui é uma entidade entendida de modo globalizado. Uma realidade que forma um sistema. Um sistema que tem suas próprias leis e normas. Normas que, se obviamente precisam dos indivíduos para poderem se concretizar, ditam a esses indivíduos como devem ser atualizadas e materializadas. (Da Matta, 1991, p. 15)

O texto acima nos interessa de perto porque nele Da Matta assume uma posição clara contra uma ciência social subjetivista que pretende reduzir a complexidade social à referência às intenções individuais dos agentes. É uma crítica correta e bem-feita. Segundo sua concepção de sociedade, temos de buscar no próprio sistema social as leis e normas que explicam o comportamento dos indivíduos que o compõem. Deve-se procurar descobrir, portanto, a "gramática social profunda" da sociedade em questão, a qual é sempre, em grande parte, insconsciente ou inarticulada na consciência dos indivíduos que a compõem, para que possamos interpretar o comportamento destes e a lógica da própria dinâmica social.

Vimos que, segundo Da Matta, essa gramática social profunda, no caso brasileiro, apresenta uma peculiaridade: ela é dual (ao contrário da dos Estados Unidos, por exemplo, que seria unitária) e composta por dois princípios antagônicos, o individuo das relações impessoais e a pessoa das relações de compadrio e de amizade. Vejamos com cuidado os pressupostos desses dois tipos de relações sociais. Sabemos que em sociedades modernas os dois poderes impessoais mais importantes são o Estado e o mercado capitalistas. Essas são também as instituições que Da Matta tem em mente quando se refere ao mundo competitivo, hostil, das regras gerais e impessoais associadas à competição capitalista e ao aparelho repressivo do Estado. Em oposição a este mundo teríamos o mundo da casa, onde as relações se regem pela afetividade e todos são supercidadãos. Esse seria o lugar onde os brasileiros se sentiriam bem e onde poderiam desenvolver sua decantada cordialidade.

Existe, no entanto, um problema básico nesse quadro à primeira vista bem arrumado que precisaria ser explicado: qual é o conjunto de regras ou normas que explica e constitui a articulação entre esses dois mundos? Se Da Matta pretende explicar as normas e regras sociais últimas que esclarecem nossa singularidade, então a forma de articulação entre esses dois princípios tem de ser explicada. A dualidade enquanto tal é uma simples aporia. Sem estar determinada nas suas regras, ela pode ser usada ad hoc para o esclarecimento de um semnúmero de questões, ressaltando-se a importância ora de um, ora de outro princípio. Mas a questão parece-me ser: o que faz com que precisamente nesses casos tal ou qual princípio seja mais ou menos eficiente? Essa questão nunca é respondida por Da Matta. O último horizonte explicativo é sempre uma dualidade indeterminada que varia ao sabor das situações concretas examinadas.

A idéia de uma gramática social profunda só tem sentido se for possível determinar a hierarquia valorativa que preside a institucionalização de estímulos seletivos para a conduta dos indivíduos que a compõem. Essa seletividade, por sua vez, exige a consideração da variável do poder relativo de grupos e classes envolvidos na luta social por hegemonia ideológica e material. Desse modo, para clássicos da Sociologia que lidaram com a questão da institucionalização diferencial de valores e concepções de mundo como Max Weber e Norbert Elias, a questão de se determinar a hierarquia de valores que logra comandar uma sociedade específica exige a articulação da relação entre valores e estratificação social. Afinal, é a imbricação entre domínio ideológico e acesso diferencial a bens ideais ou materiais escassos que cumpre esclarecer.

Nesse sentido, para os dois autores citados acima, a vinculação entre concepções de mundo (no sentido de conjuntos articulados de normas e valores) e estratos sociais que servem de suportesa essas concepções de mundo é fundamental. Aqui não se trata da causalidade materialista marxista, a qual reintroduz por outros meios a noção de subjetividade individual transformada agora em sujeito coletivo, ${ }^{3}$ com conseqüências deletérias para a análise social. A noção de suporte social de valores e normas refere-se, ao contrário, a processos inintencionais sem sujeito através dos quais grupos e classes identificam-se com valores e são ao mesmo tempo perpassados e dirigidos por eles na dinâmica social. ${ }^{4}$ 
Nós não encontramos classes e grupos sociais na obra de Roberto Da Matta. O tema da estratificação social e a relação desta com valores desempenha um papel, na melhor das hipóteses, marginal no seu esquema explicativo. Na reflexão de Da Matta encontramos apenas indivíduos e "espaços" sociais. Minha hipótese neste texto é que isso impede que ele tenha acesso à gramática social da sociedade brasileira como definida por ele próprio acima. É que, desvinculada de uma teoria da estratificação social que explique como e por que esses valores e não outros lograram institucionalizar-se, toda a temática da relação com valores torna-se externa e indeterminada. Valores passam a ser concebidos como alguma coisa que existe independente de sua institucionalização, agindo de forma misteriosa sobre indivíduos e espaços sociais. Vejamos alguns exemplos.

Quando, então, digo que "casa" e "rua" são categorias sociológicas para os brasileiros, estou afirmando que, entre nós, estas palavras não designam simplesmente espaços geográficos ou coisas físicas mensuráveis, mas acima de tudo entidades morais, esferas de ação social, províncias éticas dotadas de positividade, domínios culturais institucionalizados e, por causa disso, capazes de despertar emoções, reações, leis, orações, músicas, e imagens esteticamente emolduradas e inspiradas. (Da Matta, 1991, p. 17)

Para o autor, portanto, casa e rua não são apenas "espaços" antagônicos e relacionados, mas também "esferas de ação social" específicas. Em cada uma dessas esferas existem valores e idéias específicas que guiam ou influenciam o comportamento dos agentes em determinada direção em cada caso. Sabemos também que, para Da Matta, esses valores, no mundo do indivíduo, apontam para uma concepção de mundo impessoal que enfatiza a igualdade e a competição entre iguais, ao passo que no mundo da pessoa teríamos o reino dos sentimentos, do particular, portanto, e de uma hierarquia baseada na afeição (que é sempre gradativa e particularizante).

O que passa então a ser imediatamente problemático é explicar a própria possibilidade de existência desses espaços tão antagônicos. Todas as vezes que enfrenta essa questão, Da Matta faz referência à obra de Max Weber e às discussões desse autor acerca do tema das éticas sociais dúplices ou múltiplas típicas de sociedades tradicionais ou semitradicionais (Da Matta, 1991, pp. 50, 52, 69 e 98; ou ainda 1981, p. 178). Isso é sem dúvida correto. Faz parte da interpretação weberiana do desenvolvimento ocidental demonstrar como havia a necessidade de se explicar o aparecimento de uma ética unitária dentro do contexto da própria concepção de mundo tradicional e religiosamente motivada. A rápida expansão, no alvorecer da modernidade, da ética ascética protestante, com sua concentração em objetivos intramundanos e singularizados e não mais dúplices ou contraditórios, ajuda, sem dúvida, a explicar o enorme impulso que essa idéia representou para o progresso material da cultura ocidental.

No entanto, como a bela metáfora do manto do santo que se transforma em gaiola de ferro, apresentada ao final de $A$ ética protestante $e$ o espirito do capitalismo, nos lembra, nós, habitantes do mundo impessoal moderno, podemos abdicar desse incentivo subjetivo. Os homens religiosos do alvorecer da modernidade tinham a possibilidade de escolher se seguiriam uma ética múltipla tradicional ou se optariam pela ética única da nova religião. O fato de nós, modernos, não termos mais essa opção significa, para Weber, que as instituições impessoais do capitalismo moderno, principalmente o mercado competitivo e o Estado burocrático, criam estímulos para a conduta individual que não estão mais à disposição da volição dos agentes. Nós somos, em grande parte, até em nossas emoções mais íntimas, produto das necessidades da reprodução institucional do Estado e do mercado. É para esse fato fundamental que Weber quer apontar com o uso de suas metáforas mais conhecidas como "gaiola de ferro" ou "destino".

Aqui não se trata apenas de uma visão weberiana. Todos os grandes clássicos da Sociologia estão de acordo nesse ponto. Para um pensador como Georg Simmel, por exemplo, o domínio do mercado como instituição fundamental do mundo moderno, ou, nas suas palavras, o advento da economia monetária, significa uma redefinição da consciência 
subjetiva individual de enormes proporções. As noções básicas de tempo e espaço se modificam, e com elas se modificam também toda a economia emocional, a vida afetiva individual e recôndita de cada um de nós, como a forma da atração sexual entre os dois sexos, a necessidade de distanciamento interno e externo que os contatos impessoais da vida nas metrópoles exigem, a entronização do princípio da calculabilidade como alfa e ômega da personalidade individual, a indiferença e o sentimento blasé como emoções típicas da indiferenciação qualitativa operada pelo dinheiro transformado em meio universal de troca etc. ${ }^{5}$

Não só a economia, mas também o Estado é um poderoso elemento transformador da vida individual. Talvez ninguém melhor do que Norbert Elias tenha tido tanta consciência desse fato. Para Elias, o Estado moderno, com o seu monopólio da violência física na sociedade, é apenas a ponta mais visível de um desenvolvimento milenar nas formas de exercício da dominação política, cujo pressuposto é uma completa modificação da psique individual. Ao invés do controle externo, a partir da ameaça do mais forte, o Estado moderno pressupõe controle interno e competição pelos bens escassos por meios mais ou menos pacíficos.

Elias (1989, especialmente vol. II) demonstra, com farto material empírico, como o processo de centralização do Estado moderno, com seu aparato jurídico baseado em leis gerais e no monopólio da violência, é concomitante à transformação do aparelho psíquico individual no sentido da formação de uma economia emocional específica, com um id tornado inconsciente, onde as emoções e desejos agora impossíveis de serem vividos se concentram e são reprimidos, e um superego encarregado agora, como uma instância interna ao próprio mecanismo psíquico individual, pela repressão, sublimação e reorientação de manifestações percebidas como anti-sociais. Para Elias, toda a estrutura da psique individual como vista por Freud seria o resultado (e pressuposto) histórico das modificações introduzidas pelo Estado moderno e por seu aparato de regulação social.

Desse modo, os poderes impessoais que criam o "indivíduo" não limitam sua extraordinária eficácia ao mundo da rua. Eles entram dentro da casa de cada um de nós e nos dizem, em grande medida, como devemos agir, o que devemos desejar e como devemos sentir. Ao contrário do que supõe a dualidade damattiana, os poderes impessoais (que criam o "indivíduo") do mercado e do Estado não são instituições que exercem seus efeitos em áreas circunscritas e depois se ausentam nos contatos face a face da vida cotidiana. Eles jamais se ausentam e na verdade penetram até nos mais recônditos esconderijos da consciência de cada um de nós. A dualidade damattiana pressupõe a perda da eficácia específica das instituições que criam o mundo moderno. O vínculo fundamental entre eficácia institucional e predisposição valorativa individual não é levado em conta no raciocínio do autor. Os valores são percebidos como tendo existência independente da vida institucional.

Desligando a dinâmica valorativa social tanto de uma relação com a estratificação social quanto da referência à eficácia institucional, pode então Da Matta referir-se a indivíduos que se contrapõem em "espaços" sociais distintos, os quais carecem de qualquer determinação estrutural. Vejamos as conseqüências disso para o seu conceito de cidadania:

Se no universo da casa sou um supercidadão, pois ali só tenho direitos e nenhum dever, no mundo da rua sou um subcidadão, já que as regras universais da cidadania sempre me definem por minhas determinações negativas: pelos meus deveres e obrigações, pela lógica do "não pode" e "não deve”. (Da Matta, 1991, p. 100)

Aqui observamos que as duas lógicas antagônicas conduzem a um curto-circuito sociológico ao equalizar esferas de ação a "espaços" específicos. ${ }^{6}$ Desse modo, supercidadania e subcidadania tornam-se uma variável dependente do "espaço" social onde me encontro. Seria razoável supor que uma operária negra e pobre da periferia de São Paulo que, depois de trabalhar o dia inteiro e ter efetivamente fartas experiências de subcidadania na "rua", apanha do marido em "casa" sente-se uma supercidadã? ${ }^{7}$

Todos sabemos que não apenas as mulheres negras e pobres, mas todos os grupos sociais 
oprimidos enfrentam situações de subcidadania independentemente do lugar ou do "espaço social" onde se encontram. A não referência à estratificação social de acordo com classes e grupos específicos cria uma ilusão de "espaços" com positividade própria. Da Matta (1991, p. 100) é inclusive obrigado a apelar para explicações subjetivistas que ele próprio havia condenado como má sociologia:

Se minha visão do Brasil a partir da casa é que "a nossa sociedade é uma grande família”, com um lugar para todos, na esfera da rua minha visão de Brasil é muito diferente. Aqui eu estou em "plena luta" e a vida é um combate entre estranhos. Estou também sujeito às leis impessoais do mecado e da cidadania que freqüentemente dizem que eu "não sou ninguém". Fico, então, à mercê de quem quer que esteja manipulando a ordem social naquele momento.

O fato de a dominação em última instância ser feita em favor de um "alguém" que esteja "manipulando a ordem social" é sintomático da dificuldade apontada acima. Afinal, era o próprio Da Matta quem pretendia superar o subjetivismo sociológico que atribui a explicação última da lógica social à intencionalidade individual. É sem dúvida mais fácil explicar o funcionamento de regras sociais a partir da intencionalidade dos agentes. Afinal, é assim que nós nos percebemos no senso comum, e é da força do senso comum, como nos ensina Charles Taylor (1997, especialmente cap. I), que o ponto de partida subjetivista ou "naturalista" retira sua força peculiar e evidência. $O$ caminho de quem pretende descobrir a gramática social profunda de uma formação social, no entanto, é mais espinhoso. São as normas e regras sociais implícitas que hierarquizam uma sociedade. Indivíduos ou classes dominantes são, no máximo, suportes desses valores e normas, mas de modo algum, sujeitos intencionais desse processo.

Da Matta é forçado a buscar uma solução intencionalista para a questão do poder precisamente, vale a pena repetir, porque apenas as regras sociais anteriores e por trás da dualidade indivíduo/pessoa e casa/rua é que poderiam explicar a relação entre os dois princípios. É porque Da Matta interrompe sua busca da gramática profunda brasileira na afirmação da própria dualidade que a relação entre os dois termos e, por conseqüência, a própria noção de "relação" é sempre indeterminada. Um outro exemplo pode talvez ajudar a esclarecer esse ponto:

\begin{abstract}
Mas se a categoria profissional — os trabalhadores como cidadãos e não mais como empregados tem uma ligação forte com o Estado, ou governo, então eles podem ser diferenciados e tratados com privilégios. É a relação que explica a perversão e a variação da cidadania, deixando perceber o que ocorre no caso das diversas categorias ocupacionais no Brasil, onde elas formam uma nítida hierarquia em termos de sua proximidade do poder, ou melhor, daquilo que representa o centro do poder. (Da Matta, 1991, p. 85)
\end{abstract}

O que significa, nesse contexto, uma "forte ligação" com o Estado? Poder-se-ia perceber essa relação a partir do esforço de um Estado modernizador de premiar e constituir vínculos de lealdade com setores das classes trabalhadoras que contribuíam no esforço nacional de modernização. Mas aí já estaríamos falando de valores, dos quais o Estado nacional seria, ainda que parcialmente, suporte. E esses valores é que definiriam quais setores seriam ou não privilegiados e por quê. Estaríamos falando de valores inscritos e institucionalizados na realidade social cotidiana, portanto, que ajudam a determinar o conceito de poder nessa situação, esclarecendo seu uso e sua lógica. Esse, no entanto, não é o caminho de Da Matta.

Quando o autor se refere a uma hierarquia definida a partir da "proximidade com o poder", não temos a menor idéia de quais valores, regras ou normas explicam essa hierarquia. Poder torna-se aqui um conceito amorfo e indeterminado, já que não compreendemos o que a proximidade ou a distância em relação a ele significam. As palavras aqui, mais uma vez, nutrem sua eficácia do discurso comum, na medida em que é imediatamente compreensivel para qualquer pessoa que "quem se relaciona" ou "está próximo" do poder tem privilégios. 
De resto, a sociologia "relacional" de Da Matta parece retirar sua evidência menos da conscientização dos pressupostos valorativos subjacentes à nossa cultura e que não haviam sido percebidos até então, como ele próprio supõe, do que, precisamente, do fato contrário: do fato de permitir a sistematização da imagem do senso comum, da "ideologia" do brasileiro médio acerca de si próprio. Acredito que a própria oposição entre indivíduo e pessoa e entre casa e rua só mantém sua evidência quando não nos perguntamos acerca dos seus pressupostos.

Afinal, a separação entre as esferas do "indivíduo" e da "pessoa" e entre os "espaços" da casa e da rua é típica de toda sociedade moderna e complexa e não atributo de uma sociedade tradicional ou semitradicional como Da Matta percebe o Brasil. A confusão entre as esferas públicas e privadas (casa e rua, na linguagem damattiana) é que é uma característica típica de sociedades tradicionais e patrimoniais pouco diferenciadas. A noção de indivíduo como usada por Da Matta, para especificar a cultura ocidental moderna e desenvolvida, na verdade não existe desse modo em nenhuma sociedade concreta, muito menos nos EUA, como acredita o autor. Creio que por trás da evidência dessas noções se esconde uma noção indiferenciada do indivíduo ocidental moderno. ${ }^{8}$ Senão, vejamos.

Uma genealogia do indivíduo moderno como a elaborada por Charles Taylor (1997) no seu As fontes do self mostra que essa noção é bem mais rica, contraditória e matizada. O elemento universalizante ao qual Da Matta faz referência seria sem dúvida um de seus componentes fundantes, mas não o único. Esse componente normalizante e generalizante seria o que Taylor chama de "self pontual”, para enfatizar o elemento disciplinável que será a matéria-prima das burocracias da economia e da política modernas. No entanto, essa noção está longe de contar toda a história do individualismo ocidental.

Se o "self pontual" permite as construções generalizantes da política (cidadania) e da economia (o sujeito contratual), conferindo sentido à noção de "dignidade" moderna, é apenas com uma outra fonte do individualismo moderno, o que
Taylor chama de "autenticidade", que alcançamos um quadro mais completo do indivíduo moderno ocidental. Na busca por autenticidade temos a procura por características específicas e particulares a cada um de nós, referindo-se à nossa diferença específica e a relações e objetos que são particulares e não generalizáveis, na medida em que são hierarquizados em sua importância por nossos afetos e sentimentos.

Na idéia de autenticidade, é a noção de profundidade do self que muda. A revolução nos costumes da década de 60 é vista por Taylor como um momento especialmente importante para a eficácia social dessa noção, na medida em que seus princípios saem da vanguarda artística e logram influenciar decisivamente o senso comum de toda uma geração com efeitos permanentes. O que há de revolucionário na noção de autenticidade é a idéia de uma individuação mais completa e original.

Nesse sentido, as profundezas do self deixam de ser sinônimo de erro e engano, num caminho que havia sido originalmente traçado por Montaigne e Rousseau. Essa mudança é expressa na passagem das paixões aos sentimentos. Estes são renomeados e reabilitados, tornando-se normativos o que as paixões não eram. Agora, descobrimos o que é certo, nós indivíduos modernos do limiar do século XXI, ao menos em parte, experenciando nossos sentimentos.

Para Taylor, esse renascimento e nobilitação do sentimento é um traço marcante da cultura moderna. A vida social moderna contém, portanto, as duas vertentes da configuração moral ocidental, baseada numa noção dúplice de indivíduo: a noção de dignidade generalizável, cujo lugar privilegiado é a economia e o mundo do trabalho, e a noção de autenticidade, que tem no casamento baseado em sentimentos e na constituição de um espaço de intimidade e cumplicidade compartilhada talvez sua objetificação mais importante. A casa e a rua, portanto, dimensões que Da Matta supõe tão brasileiras, são construções sociais que se tornam possíveis apenas no mundo moderno e diferenciado de sociedades complexas e dinâmicas.

Não é apenas Charles Taylor que desenvolve essa dualidade do indivíduo ocidental, embora ele certamente seja dos que mais contribuíram para a 
percepção de um conceito diferenciado e complexo do indivíduo ocidental. Com outras denominações, essa dualidade é amplamente aceita na Sociologia moderna. ${ }^{9}$ O ponto essencial aqui é que o elemento expressivo e afetivo da personalidade individual é levado em conta como componente constitutivo da noção de indivíduo moderno. A alternativa damattiana entre indivíduo e pessoa refere-se, na realidade, a dimensões distintas do mesmo conceito de indivíduo, o qual só encontra condições de desenvolvimento em sociedades modernas e complexas. ${ }^{10}$

Sem dúvida as noções de autenticidade e individualização expressiva não cobrem todo o horizonte da noção de pessoa em Da Matta. Além do aspecto do mundo emocional e do particularismo que ela implica, Da Matta chama a atenção para um dado que seria peculiarmente brasileiro na noção de pessoa: a troca de favores, o jeitinho, a "carteirada" - em uma palavra, a tendência à corrupção e à refração da lei geral. O mundo da política seria a esfera privilegiada dessa inclinação nacional, a qual não passaria despercebida aos "indivíduos", aos homens comuns sem meios de troca nesse comércio generalizado de favores.

O resultado não passa, porém, despercebido à massa brasileira que vê na atividade política um jogo fundamentalmente sujo, onde existe de tudo, menos ética. Daí a expressão "fulano é muito político" para exprimir alguém que sabe cuidar de seus interesses pessoais. (Da Matta, 1991, p. 94)

Seria, efetivamente, uma idiossincrasia brasileira a visão da política como um jogo desonesto entre pessoas que trocam favores e proteção? Não creio. Em famosa pesquisa empírica realizada por Bellah e sua equipe nos EUA, também a política enquanto tal, especialmente a grande política do Estado e da negociação partidária, é vista como "suja" pela grande maioria dos americanos.

Nas nossas entrevistas, ficou claro que para a maioria das pessoas com quem falamos, os marcos da verdade e da virtude são percebidos como encontráveis nas relações de intimidade e nas experiências mais pessoais. Tanto a situação social das classes médias, quanto o vocabulário da vida cotidiana já predispõem para a orientação no sentido das fontes privadas e pessoais de sentido. Nós também percebemos uma forte identificação com relação aos Estados Unidos como comunidade nacional. No entanto, apesar de a nação ser vista como boa, tanto "governo" quanto "política" possuem freqüentemente conotações negativas. Os americanos, ao que parece, são genuinamente ambivalentes com relação à vida pública, e essa ambivalência implica dificuldades de perceber os problemas que confrontam a todos. (Bellah et al., 1986, p. 250; tradução minha)

Volto ao fio condutor dessa argumentação. É a imagem (no caso, desvalorizada) do brasileiro acerca de si mesmo que é dramatizada na teoria damattiana. Afinal, por que supor uma tendência inata dos brasileiros à corrupção e ao estabelecimento de relações de favores? Seria essa "predisposição" maior aqui do que em qualquer outro país? Recentemente, foi descoberto na Alemanha Federal um esquema de corrupção e favorecimento político com 25 anos de estabilidade e incrível eficiência, que faria qualquer Fernando Collor brasileiro morder os lábios de inveja. ${ }^{11}$ Admitamos, por hipótese, que, desgraçadamente, o grau de corrupção no Brasil seja maior do que em outros países. Não seria a causa desse fato uma ausência de mecanismos mais eficazes de controle, antes que uma misteriosa eficácia atávica de padrões culturais personalistas tradicionais da vida colonial brasileira?

Não seria, ao contrário, um dado estrutural da política em todos os países modernos a existência de um déficit de legitimidade, em oposição à economia, por exemplo? Essa é a opinião de Bellah na mesma pesquisa realizada nos EUA. Ao analisar a desconfiança dos americanos em relação à política, afirma o autor:

A política sofre pela comparação com o mercado. A legitimidade deste último baseia-se, em grande medida, na crença de que ele premia indivíduos imparcialmente com base numa competição justa. Por contraste, a política da negociação local, 
estadual e federal, apesar de compartilhar as mesmas atitudes utilitárias do mercado, freqüentemente expõe a competição entre grupos desiguais quanto aos recursos de poder, influência, e probidade moral, os quais influem decisivamente no resultado final. (Bellah et al., 1986, p. 200; tradução minha)

Não reconhecemos nas citações acima, nos insuspeitos EUA, precisamente a contraprova preferida de Da Matta em relação ao caso brasileiro, a mesma oposição entre mundo público hostil e mundo privado prenhe de sentido, e, mais importante, a mesma percepção do mundo da grande política, visto com desconfiança e distância? Onde estaria, nesse sentido, a especificidade brasileira?

Também esse aspecto não parece ser atributo de países tradicionais e com ética dual. A explicação de Bellah ao fato é bem distinta. A "grande política" é percebida como amoral pela grande maioria das pessoas porque em sociedades modernas e complexas a barganha politica é realizada de forma intransparente para a grande maioria (Bellah et al., 1986, pp. 207-208). Essa é uma conseqüência inevitável da institucionalização de esferas sociais segundo padrões racional-instrumentais no mundo moderno. Ao contrário do mercado, no entanto, a política precisa legitimar-se a partir da noção de uma atividade dirigida ao bem comum. O impulso utilitário que a aproxima do mercado - afinal, todo político tem sua família para sustentar e sua carreira para cuidar - precisa ser temperado e pelo menos parcialmente encoberto pelo atendimento de necessidades que devem ser percebidas como de interesse de todos. A tensão entre esses dois componentes torna a corrupção um dado estrutural da esfera política moderna. Todo político tem de lidar com a contradição de perseguir seus fins egoísticos como qualquer outra pessoa em qualquer outra atividade, e conciliar essa posição com a expectativa de que ele seja um pouco "um monge extramundano". Essa contradição me parece estar no cerne da ambigüidade entre figura privada e imagem pública que é tão determinante para o resultado de eleições.

Nesse sentido, a corrupção é um fenômeno estrutural à política e sua presença é sempre latente, o que não significa, obviamente, que não deva ser combatida e controlada. O nosso ponto aqui é mostrar que ela não tem nada a ver com o personalismo e o tradicionalismo que Da Matta identifica na sociedade brasileira. O que parece ser peculiarmente brasileiro é a manipulação populista da corrupção como tema central do debate político, num país tão carente de discussões públicas de fundo sobre escolhas coletivas fundamentais.

A razão última dessa "brasilianização" de características tão marcantes do mundo contemporâneo tem a ver, acredito, com a forma idealista pela qual Da Matta percebe a relação entre valores e sua institucionalização, assim como com a concepção indiferenciada de modernidade ocidental subjacente à sua teoria. A tentativa mais recente de Da Matta (1994, especialmente pp. 125-151) de relevar a posição do elemento intermediário e de "pensar o Brasil com base no número três" e não mais em uma "razão dualista" não resolve a questão essencial, mas apenas a desloca. A questão essencial seria a explicação da lógica social subjacente que permitiria tornar os fenômenos observáveis "determinados", ou seja, compreensíveis a partir de regras e normas sociais globais. É isso que Da Matta diz pretender e essa pretensão em si já é elogiável. Mas ele substitui, sempre que lhe convém, a busca por essas regras últimas por evidências empíricas. Isso fica claro na "institucionalização do intermediário e do número três".

Afinal, de interesse para o conhecimento seria perceber de que maneira individualismo e holismo se combinam, se institucionalizam e se estratificam de modo a produzir um terceiro elemento híbrido. Mas, se como vimos acima, Da Matta não determina a forma como individualismo e holismo se articulam, menos ainda pode ele determinar a forma como o elemento terciário derivado desses ganha vida. O que temos na análise damattiana desse ponto é, portanto, como não poderia deixar de ser, a não mediada descrição concreta de nossa paixão pelo hibridismo, indo até a caracterização algo caricatural da nossa feijoada como híbrida de sólido e líquido! O curto-circuito concretista chega às raias de um misticismo do três! Nele cabem mulatas, feijoadas e o que mais nossa imaginação possa criar. 


\section{Uma tentativa de interpretação alternativa do dilema brasileiro}

Mas, poder-se-ia perguntar, como esclarecer então as inúmeras situações flagrantes de desigualdade que abundam no nosso país, como nos mostra a análise do ritual do "você sabe com quem está falando"? Como explicar a desigualdade e a injustiça social abismal no Brasil sem buscar uma duvidosa continuidade atávica de relações pessoais todo-poderosas do passado? Como levar em conta as efetivas e profundas transformações sofridas pelo país no nosso já secular processo de modernização e, ao mesmo tempo, explicar a permanência de desigualdades tão iníquas? Afinal, era essa questão fundamental que Da Matta havia procurado responder a partir da permanência secular do personalismo e de relações sociais associadas a este. Como construir uma explicação alternativa a esse problema tão importante?

O desafio passa a ser, portanto, explicar o atraso social e político brasileiro sem apelar para explicações que enfatizem a permanência do personalismo como o núcleo da formação social brasileira. Em outro trabalho (Souza, 2000), com maior detalhe e vagar, procurei demonstrar a intima relação de noções como herança ibérica, personalismo e patrimonialismo, formando a interpretação dominante dos brasileiros sobre si mesmos, seja na esfera da reflexão metódica, seja na esfera político-institucional. Essa concepção, que tem representantes do calibre de um Sérgio Buarque ou Raymundo Faoro, além do próprio Da Matta, logrou transformar-se, de há muito, tanto em senso comum na realidade cotidiana, quanto em projeto político explícito, influenciando decisivamente nossa realidade institucional e as práticas sociais associadas a ela. De acordo com essa concepção, que poderíamos chamar de nossa "sociologia da inautenticidade", o Brasil é o "outro" ou um desvio da modernidade, tendo sido modernizado para "inglês ver", uma modernização epidérmica e de fachada.

Nos limites deste artigo procurarei me concentrar apenas em demonstrar de que modo uma adequada consideração da relação entre valores e sua institucionalização, por um lado, vinculando-a com a questão da estratificação social, por outro lado, pode ajudar a vislumbrarmos uma outra concepção do processo de modernização brasileiro. Essa visão alternativa tem, a meu ver, a vantagem de permitir perceber a sociedade brasileira no seu dinamismo e complexidade inegáveis, ou seja, permite perceber a efetiva modernização do país, ao mesmo tempo que nossa miséria e nosso atraso relativo como resultado da seletividade desse mesmo processo de modernização.

Gostaria de desenvolver a tese acima, ainda que de forma tentativa e incompleta, a partir de uma reinterpretação do trabalho de um outro clássico do pensamento social brasileiro: Gilberto Freyre. A relação entre Roberto Da Matta e Gilberto Freyre é interessante e intrigante. Por um lado, os dois são comumente percebidos como pensadores de uma vertente peculiar de pensamento social brasileiro, aquela que concentra sua atenção em aspectos normalmente não considerados pela tradição científica dominante, como rituais, costumes e hábitos cotidianos. O próprio Da Matta levanta um outro ponto em comum: os dois fariam uma sociologia de quem "gosta do Brasil", ou seja, que seria crítica da tendência pessimista de só ver defeitos no país (Da Matta, 1999b). De um ponto de vista mais analítico, noções fundamentais para Da Matta, como a oposição casa/rua, seriam influências freyrianas (Da Matta, 1991, p. 60).

No entanto, uma leitura atenta permite perceber que os dois autores partem de pressupostos distintos e chegam a conclusões que não poderiam ser mais díspares. Senão, vejamos. Já na visão da singularidade histórica brasileira, um ponto básico para a empresa teórica de ambos, a perspectiva desses autores não poderia ser mais antagônica. Enquanto Da Matta segue, no fundamental, a visão faoriana (Da Matta, 1991, p. 83) da transmissão da herança patrimonial portuguesa ao Brasil, de um Estado patrimonial centralizado e todo-poderoso que inibiria o localismo e o associativismo, Freyre parte do princípio oposto. Para Gilberto Freyre, o Brasil colonial seria um caso extremo de descentralismo político, criando as condições para um patriarcalismo que se cristaliza em mandonismo local ilimitado, pela ausência seja de instituições intermediárias acima da família, seja de efetiva ação e controle do Estado. 
A essa oposição inicial correspondem diagnósticos conflitantes acerca do que caracterizaria a modernidade do Brasil. Enquanto Da Matta parece acreditar na continuidade de um esquema rígido de poder que constitui a base empírica do seu quadro de uma sociedade hierárquica que, mesmo no contexto de uma sociedade complexa e diferenciada como a do Brasil da segunda metade do século XX, seria misteriosamente comandada por relações pessoais de família e compadrio, Freyre desenvolve um raciocínio diametralmente oposto.

Minha hipótese é que encontramos em Gilberto Freyre as bases para uma interpretação da formação social brasileira em que o dado da nossa singularidade é posto em primeiro plano. De acordo com essa interpretação, o Brasil seria uma sociedade sui generis e não uma mera continuação de Portugal. Esse ponto é fundamental, já que Freyre também enfatizou, especialmente nos seus escritos luso-tropicalistas, essa continuidade. Sem querer negar que ele tenha estimulado decisivamente também essa tradição - por exemplo, ao forjar o conceito de "plasticidade" do português, conceito esse que seria mais tarde adotado por Sérgio Buarque e que implica uma visão idealista da relação entre valores e sua institucionalização —, creio ser possível, porém, perceber uma visão alternativa na sua obra. Essa visão alternativa talvez tenha sido pouco consciente para o próprio Freyre. De qualquer modo, penso que é a partir dela que mais podemos aprender com este autor e é dela que poderemos retirar o cerne da atualidade da multifacetada obra freyriana.

Essa visão alternativa baseia-se em duas idéias principais. A primeira, que forma o núcleo do argumento de Casa-grande e senzala (Freyre, 1957 [1933]), é a idéia da sociedade colonial brasileira como uma sociedade sadomasoquista. A segunda, núcleo do argumento desenvolvido em Sobradose mucambos (Freyre, 1990 [1936]), é a idéia da constituição da modernidade brasileira sob a forma peculiar de uma "europeização" que transforma o país de alto a baixo a partir da primeira metade do século XIX.

A tese da sociedade sadomasoquista não é isenta de ambigüidades. Ela se refere ao estatuto peculiar da instituição da escravidão no Brasil. Já aqui temos uma descontinuidade fundamental em relação a Portugal. A escravidão, fenômeno marginal em Portugal, é uma instituição total no Brasil colonial. Em Freyre, a visão sobre a especificidade da escravidão brasileira alterna-se entre uma ênfase no sadomasoquismo e uma concentração no tema da mestiçagem. Essa ambigüidade é constitutiva da forma como Freyre percebe a singularidade da escravidão brasileira. Esta seria uma forma muito peculiar de escravidão, uma "escravidão muçulmana" (Freyre, 1969, pp. 179-180). Malgrado todas as características comuns a todas as formas de escravidão na América, essa forma de escravidão teria particularidades importantes.

Para Freyre, a escravidão muçulmana é aquela que repete a estratégia muçulmana nas suas guerras de conquista e escravização, que permitia ao escravo nascido de muçulmano ser equiparado a este em status caso assumisse a religião e os "valores" do pai (Freyre, 1969, p. 181). Essa astuciosa estratégia propicia uma expansão e durabilidade da conquista inigualáveis na medida em que associa o acesso a bens materiais e ideais muito concretos à identificação do dominado com os valores do opressor. A conquista pode assim abdicar da vigilância e do emprego sistemático da violência para a garantia do domínio e passar a contar crescentemente com um elemento volitivo internalizado e desejado pelo próprio oprimido. O Brasil Colônia estava cheio de exemplos desse tipo de política. Isso permitia que fossem usados aqui capitães-demato e feitores negros ou mulatos, fato impensável nos EUA, por exemplo, onde toda a atividade de vigilância e controle dos escravos era realizada exclusivamente por brancos (Degler, 1971, p. 84). Permitia também a povoação de enormes massas territoriais sem que a dominância do elemento conquistador fosse posta seriamente em perigo.

Essa astuciosa estratégia de domínio, se no pólo negativo implica subordinação e sistemática reprodução social da baixa auto-estima nos grupos dominados, no pólo positivo abre uma possibilidade efetiva e real de diferenciação social e mobilidade social. É a partir desse pólo positivo que Freyre constrói sua tese da mestiçagem como peculiaridade social brasileira. Essa construção, por secundarizar o elemento de opressão e subordinação siste- 
mática, é ideológica e conservadora no mau sentido desse termo. Ela efetivamente levou Freyre, provavelmente influenciado pela tradição germânica do "Volksgeist" (espírito do povo), ${ }^{12}$ estimulado talvez pelo seu mestre Boas, a pleitear uma espécie de "contribuição singularmente brasileira à civilização". Apenas a partir dessa idéia é que podemos compreender a contraposição que perpassa a sua obra entre a democracia racial — ou "social", como ele preferia - brasileira e a democracia "apenas política" dos norte-americanos. Esse relativismo politicamente perigoso o levaria, especialmente nas suas obras luso-tropicalistas, a toda espécie de delírio culturalista acerca de supostas especificidades culturais do moreno e mestiço, e toda sorte de elogio do autoritarismo político para a proteção dessa pretensa originalidade luso-tropical. É também o tema da mestiçagem que faz Freyre enfatizar a continuidade entre Portugal e Brasil. Este seria, afinal, um "gen cultural" herdado dos portugueses.

Não é esse Gilberto Freyre que pretendo reaproveitar aqui. Bem mais interessante, no entanto, é sua idéia da construção de uma sociedade singular no Brasil colonial - uma clara descontinuidade em relação a Portugal, portanto — dada a proeminência da escravidão e de uma forma muito peculiar desta. O tema do sadomasoquismo em Freyre ainda não foi, até onde sei, para além de citações tópicas dos casos mais escabrosos que abundam especialmente em Casa-grande e senzala, tratado sistematicamente.

Na construção do seu argumento, Gilberto Freyre retira todas as conseqüências do fato de que a família é a unidade básica, dada a distância do Estado português e de suas instituições da formação social brasileira, o que o permite interpretar o drama social da época sob a égide de um conceito psicoanalítico e da psicologia social. Na construção desse conceito, Freyre concentra-se em condicionamentos estritamente macrossociológicos, semelhantes àqueles que guiariam a reflexão de Norbert Elias (apenas seis anos mais tarde) acerca do caso europeu na passagem da Baixa à Alta Idade Média.

Antes de tudo, o caráter autárquico do domínio senhorial condicionado pela ausência de instituições acima do senhor territorial imediato era o fundamento dessa especificidade compartilhada por essas duas sociedades. Uma tal organização societária, especialmente quando o domínio da classe dominante é exercido pela via direta da violência armada (como era o caso nos dois tipos de sociedade), não propicia a constituição de freios sociais ou individuais aos desejos primários de sexo, agressividade, concupiscência ou avidez. As emoções são vividas em sua reações extremas, são expressas diretamente, e a convivência de emoções contrárias em curto intervalo de tempo é um fato natural.

A explicação sociológica para a origem desse "pecado original" da formação social brasileira, para Gilberto Freyre, exige a consideração da necessidade objetiva de um pequeno país como Portugal de solucionar o problema de como colonizar terras gigantescas pela delegação da tarefa a particulares, antes estimulando do que coibindo o privatismo e a ânsia de posse. Como resultado, não existia justiça superior à dos senhores de açúcar e gente, como em Portugal era o caso da justiça da Igreja, que decidia em última instância querelas seculares; não existia também poder policial independente que lhes pudesse exigir cumprimentos de contrato, como no caso das dívidas impagáveis de que fala Freyre; não existia ainda poder moral independente, posto que a capela era uma mera extensão da casa-grande.

É nesse contexto de total dependência dos escravos em relação ao senhor, sem a proteção que o costume e a tradição garantiam ao servo da gleba europeu e que lhe possibilitava a constituição de auto-estima e reconhecimento social independentes da vontade do senhor, que podemos compreender a especificidade do tipo de sociedade que aqui se constituiu. A proteção era discrição do senhor e estava relacionada a outra característica árabe da sociedade colonial brasiliera: a família poligâmica. Os filhos dos senhores e escravos, desde que assumissem os valores do "pai", ou seja, se eles se identificassem com ele, tinham a possibilidade de ocupar os postos intermediários em sociedade tão marcadamente bipolar. Devia haver inclusive grande concorrência seja entre os filhos ilegítimos seja entre as candidatas a concubinas pelos favores e pela proteção do senhor e de sua família. Existiam prêmios materiais e ideiais muito concretos em jogo de modo a recompensar quem 
melhor interpretasse e internalizasse como se fosse sua a vontade e os desejos do dominador. E é precisamente essa assimilação da vontade externa como se fosse própria, assimilação essa socialmente condicionada e que mata no nascedouro a própria auto-representação do dominado como um ser independente e autônomo, que o conceito de sadomasoquismo quer significar.

A importância desse tema para uma compreensão da sigularidade social e cultural brasileira não deve ser subestimada. No tipo de sociedade descrito em Casa-grande e senzala o sadomasoquismo tem os seus efeitos restritos à família poligâmica e sua complexa trama de favores e proteção, de afetos e invejas, de ódio e amor. No entanto, na sociedade brasileira analisada em Sobrados e mucambos, um Brasil que se moderniza sob impacto de uma Europa agora não mais "mourisca" como o Portugal que nos colonizou, mas já individualista e burguesa conforme os exemplos da Inglaterra, França e Alemanha, o sadomasoquismo pode ser visto como condicionando de forma muito interessante o Brasil moderno.

Em Sobrados e mucambos encontramos, ainda que em estado bruto e não desenvolvido explicitamente, uma visão absolutamente singular do processo de modernização brasileiro, a partir da consideração da relação entre valores e sua institucionalização, acrescida da preocupação com a questão do acesso diferencial por grupos e classes aos frutos da mesma. Justamente os pontos que havíamos percebido como ausentes na sociologia damattiana.

É que o processo que Freyre irá descrever neste livro sob a palavra-chave de "reeuropeização" procura perceber modificações tanto estruturais quanto culturais no processo singular de modernização brasileiro. A Europa que nos chega de navio a partir de 1808 , com a vinda da familia real e a abertura dos portos, contrapõe-se à espécie de "China tropical" que era o Brasil colonial. Uma sociedade patriarcal sadomasoquista, onde mulheres, crianças e escravos eram extensão da vontade do senhor. Uma sociedade que mal conhecia a tração animal, onde os brancos não se davam ao trabalho de andar na rua pelas próprias pernas, sendo carregados em palanquins pelos negros. Era uma sociedade movida a tração humana e primitivamente antiigualitária e antiindividualista.

É tendo esse contexto em mente que podemos compreender o que significou a reeuropeização para os brasileiros. A interpretação dominante desse processo enfatiza o caráter superficial, epidérmico, imitativo dessa transformação. É isso que permite a manutenção do paradigma do personalismo como interpretação dominante dos brasileiros sobre si mesmos até hoje. De Sérgio Buarque até Raymundo Faoro ou Roberto Da Matta, o personalismo é percebido como formando o núcleo duro da sociedade brasileira e como a única forma de exercitarmos a crítica social de nossas mazelas. Somos atrasados porque somos personalistas nessa versão largamente dominante na Sociologia entre nós. Até Gilberto Freyre, especialmente em Sobrados e mucambos, pode ser, e na maior parte das vezes foi efetivamente, interpretado nesse mesmo sentido. O brasileiro teria se europeizado para "inglês ver", passado a beber cerveja e comer pão como um inglês, passado a se vestir como um francês, mas não só as suas idéias estariam fora de lugar, como todo o seu ser seria inautêntico, uma grande farsa imitativa.

Uma leitura alternativa de Sobrados e mucambos pode nos dar uma outra visão desse processo. É que para Freyr e o personalismo, antes todo dominante, é ferido de morte com a reeuropeização. E ele é ferido de morte porque o que nos chega de navio a partir de 1808 não são apenas idéias e mercadorias exóticas. Na verdade, e esse é o ponto fundamental aqui, nos chegam as duas instituições mais importantes da sociedade moderna: Estado racional e mercado capitalista. Afinal, não é apenas a família real que nos visita, mas todo um aparato de vinte mil funcionários e o equivalente a dois terços do meio circulante português. Esse Estado, que merece o nome de racional no sentido moderno do termo, irá pela primeira vez no nosso país se concentrar no atendimento de demandas da população local, sob a forma dos inúmeros melhoramentos que são introduzidos nessa época, assim como na criação da infraestrutura para o funcionamento de comércio e indústria, como a criação de instituições de crédito e fomento à produção. 
Também a abertura dos portos não significa apenas simples expansão da troca de mercadorias. A troca de mercadorias, o comércio, irá reproduzir aqui o mesmo processo que operou alhures: funcionará como principal elemento dissolvente de relações tradicionais. Mais ainda, o comércio será acompanhado da introdução de manufaturas e até da maquinofatura. Mercadorias e máquinas não são produtos materiais quaisquer. Eles são sintoma de relações sociais de outro tipo. Eles pressupõem uma disciplina própria para seus operários e aprendizes, eles pressupõem uma nova visão da condução da vida cotidiana e até uma nova economia emocional adequada às suas necessidades. Não se precisa de uma revolução protestante ascética para se construir uma sociedade moderna: Estado e mercado fazem esse trabalho e produzem o tipo de indivíduo que precisam a partir de estímulos empíricos bastante concretos.

Estado e mercado não são o mundo da rua que pára na porta das nossas casas. Eles entram na nossa casa; mais ainda, eles entram na nossa alma e dizem o que devemos querer e como devemos sentir. É enganoso separar casa e rua (sendo a rua percebida como o mundo impessoal do Estado e do mercado, como vimos), como é enganoso supor a permanência atávica de relações personalistas numa sociedade estruturada por Estado e mercado. Já discutimos acima a importância do poder constitutivo de relações sociais de novo tipo a partir da eficácia do Estado e do mercado. Gilberto Freyre nos mostra com maestria como o personalismo, ou patriarcalismo como ele preferia, desde o início do processo de reeuropeização, é ferido de morte já na própria casa do patriarca. Seu controle sobre sua própria mulher decresce e ele é superado e vencido pelo filho formado em escolas européias que passam a atender melhor as novas necessidades do aparelho estatal e do incipiente mercado que se cria. ${ }^{13}$

Que esse processo de modernização seja paulatino, que tenha começado a partir de uma base incipiente e que tenha sido repleto de reveses e frustrações, não nos deve cegar com relação à compreensão do processo como um todo. Pode-se reconstruir a análise empírica e descritiva freyriana de modo a percebermos que a implantação incipi- ente do Estado e do mercado constitui, paralelamente ao escravismo ainda todo dominante no meio rural, uma sociedade de tipo novo nas cidades brasileiras mais importantes do século XIX. Nossa modernização não começa com o Estado interventor dos anos 30 que cai dos céus criando demiurgicamente o Brasil urbano e capitalista: esse novo Brasil moderno é gestado paulatinamente durante todo o decorrer do século anterior.

Esse ponto é importante posto que vai de encontro à interpretação, dominante entre nós, de que esse processo fundamental seria um malentendido, uma revolução para "inglês ver", epidérmica e inautêntica. Essa é uma visão idealista da relação entre valores e sua institucionalização. Freyre capta, como Max Weber na sua sociologia da religião, os dois momentos dessa complexa relação recíproca. Sem idéias e valores novos não há mudança social possível. Sem estruturas que institucionalizem esses novos valores e idéias na vida cotidiana, por outro lado, não há como eles se reproduzirem no mundo concreto. É essa relação que Freyre percebe melhor que qualquer outro intérprete que conheço desse período.

Mas reeuropeização não é apenas diferenciação social das esferas política e econômica. Reeuropeização não se confunde, portanto, com simples modernização. Ela é também índice de um padrão específico de assimilação cultural. A forma pela qual assimilamos a modernidade tem semelhança com a forma pela qual, na análise de Elias, as classes inferiores adotam o padrão cultural e o gosto das classes superiores. Elas o fazem sob o preço de uma "Verkitschung der Seele" (Elias, 1989, vol. I, p. 426), algo como, numa tradução livre, uma "ausência de originalidade da alma”. O “ kitch”, ou seja, a assimilação irrefletida, é produzida pelo prestígio de valor absoluto de tudo que tinha ou tem ainda hoje a ver com Europa. Se o valor é absoluto, isso significa que não existe distância crítica possivel em relação a ele. Aqui não se trata da inautenticidade da nossa modernidade, lembrada por vários críticos, mas precisamente do fenômeno contrário. Afinal, não é a superficialidade da assimilação que está em jogo, mas, ao contrário, sua absorção tão completa que não existe espaços de desenvolvimento de um projeto culturalmente original a partir dela. 
Foi a absorção da modernidade de fora para dentro como um valor absoluto que impediu e impede tanto a existência de distância crítica em relação a esse projeto, como também a naturalidade que encontramos nos europeus ocidentais. Os europeus, e os norte-americanos é claro — afinal, não estamos falando de geografia mas de racionalismos culturais - , podem se dar ao luxo de desenvolver um padrão próprio e peculiar de serem modernos. A ansiedade de ser moderno, a grande vontade galvanizadora nacional desde o começo da reeuropeização até hoje, nos impede que sejamos modernos ao nosso modo e até, no limite, que nos reconheçamos como tais. Toda uma gama de questões importantes se descortina a partir desse fato.

Freyre também percebe, outra óbvia correspondência com Max Weber, que toda inovação valorativa e institucional exige a identificação das classes e grupos que lhe servem de suporte. O esclarecimento dessa relação permite visualizar, ainda, em benefício de quem se deu a transformação. É nesse ponto que podemos unir as duas pontas do raciocínio que estamos desenvolvendo neste texto. É que a classe intermediária entre senhores e escravos criada pelo tipo singular de escravidão muçulmana que se desenvolveu entre nós encontra no contexto da reeuropeização, pela primeira vez, um lugar próprio e não apenas os interstícios de um sistema tão marcadamente bipolar como o escravista.

O mulato, pensado aqui mais como tipo social do que como cor de pele, filho da íntima comunicação tipicamente muçulmana entre desiguais, é o elemento que irá de certa forma equivaler ao nosso elemento mais tipicamente burguês naquela sociedade em transformação. É ele que será o aprendiz do estrangeiro nas manufaturas ou o ajudante do comerciante, estimulado pela ausência relativa daquele preconceito congênito ao elemento superior de toda sociedade escravocrata contra o trabalho manual. ${ }^{14}$ É ele também que ascenderá, pelo estudo e mérito pessoal, competindo com o elemento aristocrático branco, a funções nobres do aparelho de Estado, na vida literária, na esfera da ciência etc. Ele é o primeiro suporte do componente burguês e individualista na nossa sociedade, por incorporar o elemento de valorização pelo saber e pelo mérito pessoal. Nada mais burguês e individualista, pela oposição a toda determinação adscritiva de valores e posições herdadas familisticamente, que forma a base da estratificação social de sociedades tradicionais.

Interessante é que o padrão de ascensão social, ou de cidadania, como diríamos hoje em dia, continua, no século XIX, o mesmo da época colonial: o princípio do escravismo muçulmano. Ele se dá individualmente e para aqueles que se identificam com os valores do dominador, no caso, agora, já os valores impessoais do individualismo europeu. É apenas o mulato talentoso, estudioso e apto que ascende. Apenas aquele que se "europeí$z a$ ". Mais interessante ainda é notar que no século $\mathrm{XX}$, quando os valores da modernidade já têm como suporte o Estado interventor, os setores e grupos que ascendem à cidadania, à cidadania regulada, no caso (ver Santos, 1998, pp. 103-109), são também aqueles que se identificam com o projeto modernizador estatal. A sociedade se impessoaliza mas a regra da inclusão e da exclusão se mantém.

Esse ponto é importante posto que descobre uma especificidade fundamental de nossa sociedade. Aqui a ascensão social não se deu, como na Europa, coletivamente. Na esteira de Weber, Charles Taylor (1997, especialmente pp. 273-300) percebe que a auto-estima protestante, baseada na noção de trabalho sagrado, inverte a ordem do mundo tradicional em todas as suas dimensões, especialmente na esfera política. A noção de trabalho intramundano como o caminho especificamente protestante de salvação é revolucionária em dois sentidos fundamentais. Primeiro, ela reverte o ideário, que vingava desde a Antiguidade, da preponderância da contemplação sobre a ação, ou do trabalho contemplativo sobre o trabalho manual e prático, acarretando aquilo que Taylor chama de "afirmação da vida cotidiana". Ocorre uma espécie de inversão valorativa de 180 graus: as atividades práticas e manuais são valorizadas à custa do desprestígio de qualquer esforço contemplativo "inútil". O simples marceneiro vale mais do que o filósofo na sua torre de marfim. ${ }^{15}$ Essa idéia é intrinsecamente democrática, já que implica a deslegitimização da hierarquia social, estamental e 
tradicional, associada à desqualificação do trabalho manual e pragmático.

Em segundo lugar, ela é revolucionária no sentido de que a dignidade individual, ou, em termos políticos, o direito à cidadania passa a ser vinculado ao trabalho. A ascensão da burguesia se dá quando a crítica à aristocracia como classe ociosa, que não "trabalha", ganha legitimidade em amplas camadas da sociedade. Também a ascensão do proletariado se deve ao prestígio do valortrabalho. Nesse sentido, uma concepção como a do valor-trabalho marxista só se torna compreensível num contexto em que a revolução protestante tenha fincado raízes sólidas e influenciado, inclusive, países católicos, como é o caso paradigmático da França. A enorme eficácia social das teorias políticas seculares do valor social do trabalho, que permitem a ascensão política do proletariado no decorrer do século XIX, apóia-se, vicariamente, na revalorização protestante do trabalho útil.

Também foi o trabalho que permitiu a uniformização de uma economia emocional para todos os estratos na sociedade moderna. A burguesia, como primeira camada dirigente da história que trabalha (Elias, 1989, vol. II, pp. 434-455), possibilitou a produção de um tipo uniforme de ser humano, a partir do compartilhamento da relação típica entre emoções e razão exigida pela produção capitalista, como calculabilidade, previsibilidade, maior importância da satisfação adiada de necessidades etc. Nos mais variados sentidos, portanto, o trabalho revalorizado é o pressuposto do mundo moderno como o conhecemos, sendo, inclusive, um pressuposto da idéia de cidadania moderna baseada na noção da igualdade do valor de cada um, na medida em que todos trabalham e contribuem igualmente para o desenvolvimento da coletividade.

Nesse sentido, divergindo em parte do que pensa Wanderley Guilherme dos Santos, o arguto propositor desse conceito, não creio que o problemático na noção de cidadania regulada seja o fato de a cidadania não se originar "da expansão dos valores inerentes ao conceito de membro da comunidade", na medida em que esses "valores inerentes ao conceito de membro da comunidade" até bem pouco tempo ${ }^{16}$ eram corolário do princípio de que os homens são iguais porque trabalham e seu trabalho possui um valor tendencialmente intercambiável. O interesse da noção de cidadania regulada reside, a meu ver, em outro lugar. Antes de tudo no fato de sua seletividade estar ligada ao esforço de modernização tendo o Estado como suporte, ou seja, no fato de que algumas funções ou profissões são tidas como mais importantes do que outras para o esforço societário de modernização, invertendo a tendência equalizante que predominou nos países centrais do Ocidente, pondo a nu, dessa forma, uma sobrevivência histórica de longa duração. ${ }^{17}$ Nesse último aspecto, ela mostra uma surpreendente continuidade histórica, evidentemente sob outras formas, agora impessoais, da regra de inclusão e exclusão vigente desde o Brasil Colônia. Esta implica, desde a "escravidão muçulmana”, a cooptação sistemática dos membros mais capazes das classes populares, explicando a convivência de miséria intermitente com real possibilidade de ascensão social para os setores desprivilegiados que sempre caracterizou nosso país. Ajuda também a que se perceba a miséria, ao menos parcialmente, como fracasso individual.

Desse modo, fato que ajuda a relativizar e matizar o argumento que venho desenvolvendo ao longo deste artigo acerca da necessidade de considerarmos a eficácia institucional do Estado e do mercado, essas duas instituições estruturais não foram suficientes para possibilitar, por si mesmas, a homogeneização das condições e oportunidades sociais. É que o mesmo conjunto de circunstâncias que constituíram o Brasil moderno é apenas a contraface de um processo maior que cria a nossa miséria e desigualdade. A paulatina decadência da economia e da sociedade escravocratas, o setor menos dinâmico da dualidade transicional que se constitui na época da reeuropeização, vai expulsar para a margem do sistema toda uma legião de inadaptados ao novo sistema vencedor. São eles que vão constituir nossos párias urbanos e rurais desde então.

O fato de a Europa moderna não ter tido sua gênese em sociedades escravocratas, como lembra Elias ao ressaltar sua ruptura em relação a essa herança do mundo antigo, facilitou esse processo de equilíbrio entre as diversas classes e a univer- 
salização da categoria de cidadão. O cidadão é precisamente o resultado do longo processo de substituição da regulação externa pela regulação interna da conduta. Ele não só tem os mesmos direitos, mas também a mesma economia emocional. O reconhecimento da interdependência entre as diversas classes que trabalham, acordo só possível quando a primeira classe dirigente da história que trabalha, a burguesia, assume o poder, propiciou uma equalização efetiva internamente a cada espaço nacional. Foi criado um tipo humano uniforme, seja na sua organização afetiva, seja na sua organização racional e valorativa, uniformidade essa percebida por Elias como o pressuposto estrutural do cidadão moderno. É justamente essa consciência da interdependência social que é obstaculizada em sociedades tão influenciadas pelo escravismo como a nossa (ver Elias, 1989, vol. II, p. 70).

No caso brasileiro, o processo de modernização que torna a sociedade escravocrata caduca a partir da primeira metade do século XIX abandona à própria sorte toda uma classe, a dos escravos, que jamais irá recuperar qualquer função produtiva na nova ordem. É aí que se cria uma classe de párias urbanos e rurais que valem, não só para uma elite má mas, objetivamente, para toda a sociedade, inclusive para as próprias vítimas, menos do que outros. Nesse contexto não existe, objetivamente, cidadania, mas apenas sub e supercidadãos. Mas não é, como afirma Da Matta, o não acesso a relações personalistas privilegiadas que acarreta a subcidadania. São valores objetivamente inscritos na nossa lógica institucional e no âmago do nosso senso comum, sendo resultado da forma singular pela qual fomos efetivamente, e não epidermicamente como pensa Da Matta, modernizados. ${ }^{18}$

A tematização do nosso atraso, miséria e desigualdade não precisa do paradigma personalista para ser criticado. Essa idéia, primeiro gestada por pensadores em universidades e depois transformada em projeto político e prática social e institucional, reveste o brasileiro de hoje como uma segunda pele, com conseqüências e efeitos deletérios. O projeto político do personalismo, especialmente na sua versão patrimonialista, é o programa político hegemônico tanto dos ocupantes do poder quanto da oposição. Para o projeto político no poder, o programa é racionalizar o Estado de modo a estimular a competição e eficiência do mercado. Na oposição, o mote é a crítica populista à corrupção, esse dado estrutural da política moderna, que no patrimonialismo transformado em senso comum adquire contornos de especificidade brasileira. Os aparentes contendores lutam num mesmo campo comum de idéias.

Essa concepção pressupõe que a política é uma atividade intra-estatal e esquece uma terceira instituição, além de Estado e mercado, que veio modificar fundamentalmente a vida pública e privada modernas: a esfera pública. Habermas, e nisso reside sua importância seminal para a Sociologia contemporânea, foi o teórico da lógica específica a essa instituição. Uma discussão pública da função dessa esfera social fundamental jamais foi realizada entre nós, embora seja indispensável e talvez o passo mais importante para o resgate material e simbólico dos nossos miseráveis. São questões que ficam no limbo na interpretação personalista e patrimonialista de nossa reflexão teórica e das práticas sociais e institucionais que se formam a partir dela.

\section{NOTAS}

1 Veremos mais adiante que essa atitude é a raiz daquilo que iremos criticar como "concretismo fora de lugar".

2 O dualismo às vezes é interpretado como um esquema tripartite também, onde além da casa e da rua teríamos o "outro mundo". Cf. Da Matta (1991, p. 68).

3 Refiro-me aqui às aporias que marcaram boa parte do assim chamado "marxismo ocidental", antes de tudo presentes na obra de Georg Lukács. Ver especialmente Lukács (1988).

4 A noção que explica essa relação em Weber é a de "paradoxo das conseqüências". Para uma excelente discussão desse aspecto da obra weberiana ver Cohn (1979). Em Elias, o conceito central nesse tema é o de "mecanismo" (por exemplo, o mecanismo de descentralização, base do feudalismo europeu), para indicar uma necessidade sistêmica independente da intencionalidade dos grupos e classes que sofriam sua influência. Ver Elias (1989, especialmente o vol. 2).

5 Para uma introdução ao pensamento simmeliano e para o estudo de sua abordagem dos efeitos da economia monetária sobre a personalidade individual, ver o conjunto de textos da coletânea que organizei com Berthold Oelze (1998). 
6 Essa mesma crítica de um "concretismo fora de lugar" foi feita ao Habermas da década de 60 pela sua proposição de uma oposição não mediada entre ação estratégica e ação interativa como correspondendo a "espaços" sociais distintos. Durante toda a década de 70 procurou Habermas uma articulação entre os níveis da ação social e da ordem social de modo a esclarecer essa relação. O resultado dessas investigações redundaram no seu Teoria da ação comunicativa, de 1981. Não obstante, o dualismo habermasiano ainda é, talvez, o ponto mais criticado de toda sua teoria sociológica. Ainda sobre a "fallacy of misplaced concreteness" ver Parsons (1968, pp. 29, 589 e 753).

7 Esse exemplo me foi sugerido por Marcelo Neves em conversa acerca desse tema.

8 A noção de "pessoa" é mais complexa e será discutida separadamente a seguir.

9 A oposição correspondente mais comum é aquela entre individualismo possessivo e expressivo.

10 De resto, longe de ser uma característica folcloricamente brasileira, não seria a oposição entre casa e espaço público hostil uma construção apenas possível no mundo impessoalizado moderno? Não seria uma necessidade especificamente contemporânea de países urbanizados e industrializados a produção fantasiada ou real de uma oposição entre vida pública e vida íntima, representando essa última uma espécie de "refúgio num mundo sem coração" (título de um famoso livro de Christopher Lasch sobre o tema). Não seria a matériaprima dessa extraordinária e multifacetada fábrica de ilusões chamada "Hollywood" precisamente a habilidade em manipular essa necessidade de todos nós, homens e mulheres modernas, de "proximidade", "afeto", "cumplicidade", que a união romântica entre os sexos promete numa "casa" para dois? Casa na qual os futuros filhos, amigos e parentes poderiam desfrutar de uma sociabilidade oposta à da sociedade hostil fora de nós. Por que chamar o sentimento de aconchego e de bemestar que a vida da casa e da família promete, inclusive o desejo de que essa lógica seja a dominante na nossa vida, de brasileiro? Ele me parece, ao contrário, uma característica invariante das sociedades modernas.

11 Refiro-me ao escândalo envolvendo o ex-primeiroministro alemão Helmut Kohl amplamente divulgado pela imprensa.

12 A noção de "espírito do povo" é tributária da extraordinária influência do romantismo alemão na filosofia e nas ciências sociais daquele país. O romantismo, em reação ao iluminismo e ao universalismo de origem francesa e inglesa, enfatizou a singularidade e incomparabilidade tanto da personalidade individual quanto de culturas singulares. Uma cultura é percebida como produzindo um tipo específico de ser humano com características tendencialmente incomparáveis. Para um estudo da gênese histórica dessa concepção de mundo, assim como para suas conseqüências para a singularidade cultural e política alemã, ver Souza (2000, pp. 143-158).
13 Essa dominação dos mais jovens foi tão característica nesse período que mereceu do sempre arguto Joaquim Nabuco o nome de "neocracia". Ver Freyre (1990, p. 88).

14 Aqui cabe observar que o preconceito contra o trabalho manual, como todo preconceito, espraia-se tendencialmente por todos os estratos sociais. Não obstante, os preconceitos possuem também força maior ou menor dependendo do estrato social de que estamos falando, mormente para aqueles estratos que só "possuíam as mãos" como instrumento de trabalho.

15 Não é por acaso, portanto, que essa atitude pragmática em relação ao mundo foi desenvolvida nos EUA mais que em qualquer outra sociedade do Ocidente.

16 A perda de eficácia estrutural da teoria do valor-trabalho, como resultado do prodigioso progresso tecnológico do capitalismo depois da Segunda Guerra Mundial, na medida em que o trabalho científico altamente qualificado aplicado à produção deixa de guardar qualquer relação de intercambialidade com o trabalho não qualificado, inspirou a mudança habermasiana do paradigma do valor-trabalho para a "virada lingüística" (linguistische Wende). Ver, sobre este tema, especialmente Habermas (1969, pp. 48-104). A pressuposição de igualdade dos homens e mulheres não se dá mais porque todos trabalham, mas, agora, porque todos participam com iguais direitos do mesmo horizonte lingüístico, prenhe de pressupostos e conseqüências morais.

17 A cidadania regulada seria, nessa linha de raciocínio, antes que um "achado de engenharia institucional" da Revolução de 30, como defende Santos (1998, p. 104), uma espécie de elo tardio e impessoal de uma prática secular no nosso país.

18 Um argumento importante nesse contexto e que não pode ser desenvolvido nos limites deste artigo é a tese, que defendo em detalhe no livro já citado, de que todo processo histórico concreto de modernização foi seletivo, inclusive o caso da excepcionalidade americana. Isso significa que nenhuma sociedade concreta, nem mesmo a americana, logrou desenvolver todas as virtualidades do que chamamos "cultura ocidental". Nesse sentido, nosso processo de modernização é específico apenas no seu grau de seletividade. Nossa sociologia do personalismo, ao adotar um conceito indiferenciado de racionalismo ocidental, derivado diretamente do caso concreto americano tomado como modelo absoluto, tende a perceber o caso brasileiro, precisamente por conta desse curto-circuito sociológico, como o "outro", ou um "desvio" da modernidade. Ver Souza (2000, pp. 129-270). 


\section{BIBLIOGRAFIA}

BELLAH, Robert et al. (1986), Habits of the heart: individualism and commitment in American life. Nova York, Harper and Row.

COHN, Gabriel. (1979), Crítica e resignação. São Paulo, Queiroz.

DA MATTA, Roberto. (1981), Carnavais, malandrose heróis. Rio de Janeiro, Zahar.

(1991), A casa e a rua. Rio de Janeiro, Guanabara Koogan.

(1994), Conta de mentiroso: sete ensaios de Antropologia brasileira. Rio de Janeiro, Rocco.

(1999a), O que faz o brasil, Brasil? Rio de Janeiro, Rocco.

(1999b), Entrevista à revista República. Março.

DEGLER, Carl. (1971), Neither black nor white: slavery and race relations in Brazil and United States. Madison, Wisconsin University Press

ELIAS, Norbert. (1989), Über den Prozeß der Zivilization. Frankfurt, Suhrkamp.

FREYRE, Gilberto. (1957), Casa-grande e senzala. Lisboa, Editora Livros do Brasil.

(1969), Novo Mundo nos trópicos. Rio de Janeiro, Record.

(1990), Sobrados e mucambos. Rio de Janeiro, Record.

HABERMAS, Jürgen. (1969), Technik und Wissensschaft als Ideologie. Frankfurt, Suhrkamp.

LUKÁCS, Georg. (1988), Geschichte und Klassenbewußtsein: Studien über marxistische Dialetik. Darmstadt, Westdeutsche.

PARSONS, Talcott. (1968), The structure of social action. Nova York, Free Press.

SANTOS, Wanderley Guilherme dos. (1998), Décadas de espanto e uma apologia democrática. Rio de Janeiro, Rocco.

SOUZA, Jessé. (2000), A modernização seletiva: uma reinterpretação do dilema brasileiro. Brasília, Ed. da UnB.

SOUZA, Jessé e OELZE, Berthold (orgs.). (1998), Simmel e a modernidade. Brasília, Ed. da UnB.

TAYLOR, Charles. (1997), As fontes do self: a construçâo da identidade contemporânea. São Paulo, Loyola. 